\title{
Klasifikasi Kerusakan Mutu Tomat Berdasarkan Seleksi Fitur Menggunakan $\boldsymbol{K}$-Nearest Neighbor
}

\section{NISKE ELMY PAULINA ${ }^{1}$, ZILVANHISNA EMKA FITRI ${ }^{2}$, ABDUL MADJID $^{3}$, ARIZAL MUJIBTAMALA NANDA IMRON ${ }^{4}$}

\author{
${ }^{1,2}$ Program Studi Teknik Informatika, Politeknik Negeri Jember \\ ${ }^{3}$ Program Studi Budidaya Tanaman Perkebunan, Politeknik Negeri Jember \\ ${ }^{4}$ Program Studi Teknik Elektro, Universitas Jember \\ Email: zilvanhisnaef@polije.ac.id
}

Received 18 September 2021 | Revised 1 November 2021 | Accepted 17 November 2021

\begin{abstract}
ABSTRAK
Tomat (Lycopersicum esculentum Mill.) merupakan satu komoditas unggulan pertanian karena penjualan jangka panjangnya baik. Menurunnya jumlah produktivitas dan mutu tomat disebabkan oleh curah hujan yang tinggi, cuaca dan budidaya yang tidak baik sehingga buah tomat menjadi busuk, retak, dan timbul bercak. Penyuluhan terkait peningkatan mutu tomat dinilai kurang efektif sehingga dibutuhkan sebuah sistem identifikasi kerusakan mutu buah tomat yang mampu memberikan edukasi kepada petani. Penelitian ini adalah pengembangan penelitian sebelumnya, untuk mendapatkan citra segmentasi dan ekstraksi fitur digunakan penggunaan contrast stretching dan deteksi tepi sobel. Namun kedua teknik tersebut diganti penggunaan operasi citra negatif. Didapatkan fitur yang optimal adalah gabungan fitur morfologi dan pada masing-masing sudut berdasarkan seleksi fitur. Persentasi akurasi metode KNN pada pelatihan sebesar $86.6 \%$ sedangkan akurasi pengujiannya sebesar $70 \%$.
\end{abstract}

Kata kunci: kerusakan mutu, tomat, seleksi fitur, K-Nearest Neighbor

\begin{abstract}
Tomato (Lycopersicum esculentum Mill.) is one of the leading agricultural commodities because of its good long-term sales. The decrease in the amount of productivity and quality of tomatoes is caused by high rainfall, bad weather and cultivation so that the tomatoes become rotten, cracked, and have spots. Counseling related to improving the quality of tomatoes is considered ineffective so that a system for identifying damage to the quality of tomatoes is needed that is able to provide education to farmers. This study is a development of previous research, to obtain segmented images and feature extraction using contrast stretching and sobel edge detection. However, both techniques were replaced by using negative image operations. The optimal feature is a combination of morphological features and correlations at each angle based on feature selection. The percentage of accuracy of the KNN method in training is $87 \%$, while the accuracy in the testing is $70 \%$.
\end{abstract}

Keywords: quality damage, tomato, feature selection, K-Nearest Neighbor 


\section{PENDAhUlUAN}

Tomat (Lycopersicum esculentum Mill.) adalah satu komoditas unggulan pertanian karena penjualan jangka panjangnya baik serta nilai kandungan gizi yang baik (Syukur, dkk., 2015). Tanaman tomat sangat cocok tumbuh pada dataran rendah dan dataran tinggi. Saat muda, tomat akan berwarna hijau kemudian berubah menjadi orange kemerahan saat tua (masak) (Aidah \& Tim Penerbit KBM Indonesia, 2020). Buah tomat memiliki banyak variasi bentuk seperti lonjong, pipih dan bulat. Tomat dibagi menjadi 5 jenis berdasarkan bentuknya yaitu tomat bentuk pipih (Lycopersicum esculentum Mill, var commune Bailey), tomat kentang bentuk bulat besar (Lycopersicum esculentum Mill, var grandifolium Bailey), tomat tegak bentuk lonjong (Lycopersicum esculentum Mill, var validum Bailey), tomat bentuk bulat seperti apel atau pir (Lycopersicum esculentum Mill, var pyriforme Alef.) dan tomat cherry bentuk bulat dan kecil (Lycopersicum esculentum Mill, var cerasiform (Dun) Alef) (Nurhakim, 2019).

Menurut data dari Badan Pusat Statistik tercatat bahwa jumlah produksi tomat terjadi peningkatan yang cukup signifikan pada 5 tahun terakhir pada Provinsi Jawa Timur. Pada tahun 2016, produksi tomat sebesar 60.719 ton kemudian bertambah menjadi 66.758 ton pada 2017. Namun terjadi sedikit penurunan produksi menjadi 65.585 ton tahun 2018 . Peningkatan produksi tomat menjadi 75.558 ton pada 2019 dan 83.920 ton pada 2020 (Badan Pusat Statistik, 2020). Penyebab menurunnya jumlah produktivitas dan mutu tomat disebabkan oleh cuaca, curah hujan yang tinggi dan budidaya yang tidak baik sehingga buah tomat menjadi tomat bercak, tomat retak dan tomat busuk (Fitri, dkk., 2020). Pemerintah melakukan berbagai penyuluhan dengan tujuan untuk meningkatkan mutu tanaman tomat. Namun penyuluhan tersebut masih kurang efektif, sehingga dibutuhkan sebuah sistem identifikasi kerusakan mutu buah tomat yang mampu memberikan edukasi kepada petani.

Umumnya penelitian tentang buah tomat berfokus pada identifikasi hama dan penyakit, tingkat kematangan dan sortir grade buah tomat. Pada 2013, dibuat sebuah penelitian yang mengidentifikasi citra hama tomat menggunakan GLCM dan klasifikasi Probabilistic Neural Network (PNN) sehingga mendapatkan akurasi sebesar 78.89\% (Amalia, 2013). Kemudian dilakukan pengembangan identifikasi penyakit pada citra daun menggunakan GLCM dengan metode klasifikasi $K$-Nearest Neighbor (KNN) serta didapatkan akurasi sebesar $85 \%$ (Sukmandaru, 2019). Untuk penelitian terkait tingkat kematangan tomat, biasanya berdasarkan fitur warna seperti fitur warna HSV dengan metode klasifikasi Learning Vector Quantization (LVQ) sehingga akurasinya sebesar 83.75\% (Anggriawan, dkk., 2017). Kemudian dikembangkan dengan melakukan klasifikasi kematangan buah tomat berdasarkan variasi model warna seperti CIElab, HSV dan YCbCr. Tingkat akurasi terbaik menggunakan model warna CIELab dengan akurasi $100 \%$ dan model warna HSV sebesar $95 \%$ (Astrianda, 2020). Untuk penelitian terkait penyortiran mutu buah tomat berdasarkan fitur warna HSV menggunakan LVQ mendapatkan akurasi 76.67\% (Gumawang, dkk., 2017). Terakhir, peneliti melakukan penelitian klasifikasi kerusakan mutu tomat berdasarkan 7 fitur yaitu fitur morfologi (perimeter, area dan bentuk) dan tekstur (kontras pada sudut $0^{\circ}, 45^{\circ}$, $90^{\circ}$ dan $135^{\circ}$ ) menggunakan metode backpropagation, sehingga didapatkan akurasi pelatihan sebesar $89.04 \%$ dan akurasi pengujian sebesar $81.11 \%$ (Fitri, dkk., 2020). Untuk mengembangkan penelitian tersebut, maka peneliti menerapkan seleksi fitur dan melakukan klasifikasi menggunakan metode lain seperti $K$-Nearest Neighbor. 


\section{METODE PENELITIAN}

Tahapan penelitian yang dikerjakan adalah pengumpulan dataset citra kerusakan pada buah tomat, pemecahan komponen warna RGB, konversi citra negasi, segmentasi citra, ekstraksi fitur, seleksi fitur dan klasifikasi K-Nearest Neighbor (KNN) seperti Gambar 1.

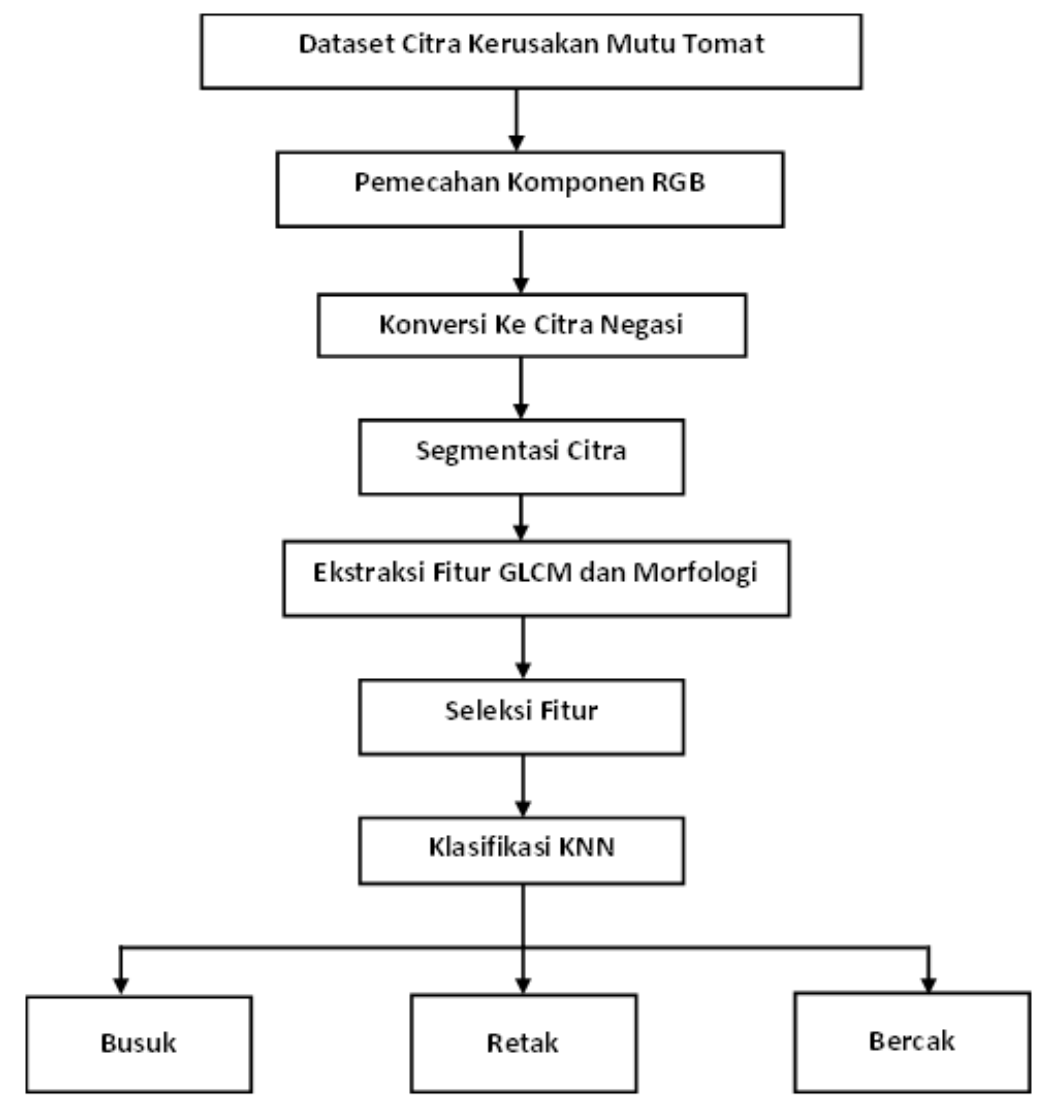

Gambar 1. Diagram Blok Identifikasi Kerusakan Mutu Tomat

\subsection{Dataset citra kerusakan mutu tomat}

Citra penelitian yang digunakan merupakan dataset citra kerusakan mutu tomat dari penelitian sebelumnya, namun ditambahkan beberapa citra baru khususnya pada kelas bercak buah (bacterial speck). Proses pengambilan data yaitu menempatkan buah tomat kedalam mini box berlatarbelakang putih. Jarak pengambilan foto antar lensa kamera dengan buah tomat yaitu $\pm 20 \mathrm{~cm}$ dan data citra kerusakan buah tomat dibagi menjadi tiga kelas yaitu bercak buah, retak buah dan busuk buah (Gambar 2).

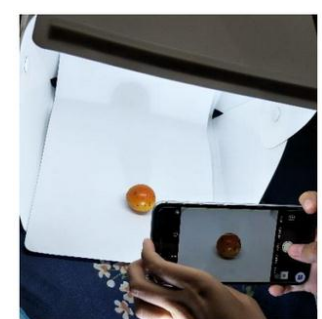

(a)

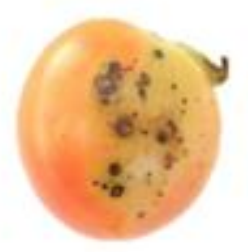

(b)

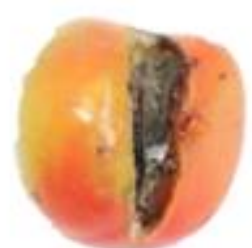

(c)

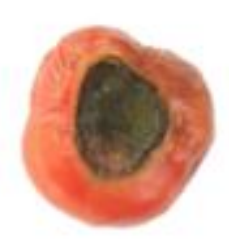

(d)

Gambar 2. (a) Pengambilan Dataset Tomat Menggunakan Mini Box, Citra (b) Bercak Buah, (c) Retak Buah dan (d) Busuk Buah 
Setelah dilakukan pengambilan dataset citra kerusakan mutu tomat, proses selanjutnya adalah proses normalisasi ukuran citra menjadi 300 × 300 piksel. Hal tersebut dilakukan karena ukuran citra asli yang digunakan berbeda-beda sehingga dibutuhkan normalisasi ukuran citra. Jumlah data latih sebanyak 210 (80 citra busuk, 80 citra bercak dan 50 citra retak) sedangkan jumlah data uji sebanyak 30 (10 citra busuk, 10 citra retak dan 10 citra bercak).

\subsection{Pemecahan Komponen RGB}

Umumnya citra yang dicapture pada smartphone adalah citra warna RGB. Model ruang warna RGB dimana setiap pikselnya terdiri dari 3 komponen intensitas warna yaitu komponen warna red, komponen warna green dan komponen warna blue. Citra tersebut berukuran besar yaitu 24 bit dan sulit untuk disegmentasikan sehingga perlu dikonversikan ke ruang warna lain (Fitri, dkk., 2017) (Nanda Imron \& Fitri, 2019). Oleh karena itu citra tersebut dilakukan proses pemecahan ketiga komponen tersebut seperti Gambar 3.

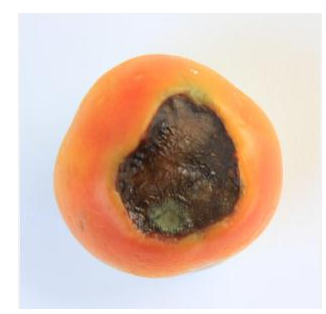

Citra Asli Tomat

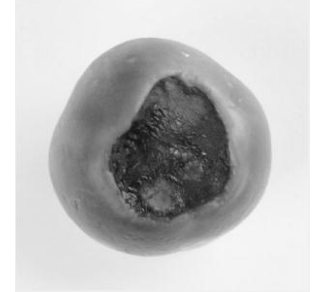

Citra Komponen Green

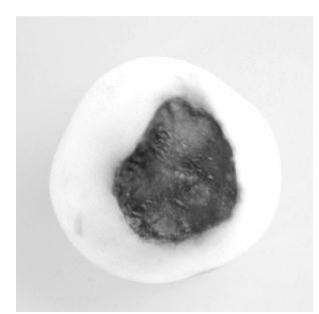

Citra Komponen Red

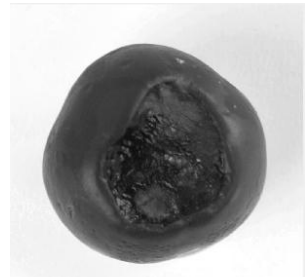

Citra Komponen Blue

\section{Gambar 3. Hasil Pemecahan Komponen Citra RGB}

Berdasarkan hasil dari Gambar 3, menunjukkan bahwa citra komponen red yang merepresentasikan kerusakan mutu tomat lebih baik dibandingkan citra komponen green dan citra komponen blue.

\subsection{Konversi Citra Negasi}

Operasi negative bertujuan untuk mendapatkan citra negatif dengan cara nilai maksimum keabuan dikurang dengan nilai intensitas pada piksel berdasarkan Persamaan :

$$
F o(x, y)=255-f_{i}(x, y)
$$

\subsection{Segmentasi Citra}

Tujuan dari segmentasi citra adalah memisahkan obyek penelitian dengan background yang sering disebut proses thresholding karena hasil dari proses ini didapatkan citra biner dengan dua nilai yaitu 0 (hitam) dan 1 (putih) menggunakan Persamaan (Fitri, dkk., 2021):

$$
S(x, y)=\left\{\begin{array}{l}
0, \text { if } f_{i}(x, y)<T \\
1, \text { if } f_{i}(x, y) \geq T
\end{array}\right.
$$

\subsection{Ekstraksi Fitur}

Fitur morfologi adalah fitur berdasarkan bentuk atau region dari obyek pada sebuah citra. Beberapa fitur yang digunakan adalah fitur area, perimeter dan faktor bentuk yang didapatkan dari proses labelling berdasarkan kode rantai. Chain Code atau kode rantai berfungsi untuk mendeskripsikan contour (bentuk) obyek dengan menggunakan kode. Pembentukan kode rantai dengan menentukan piksel pertama dari obyek dengan cara mengikuti aturan arah kode berdasarkan arah ketetanggan 4 atau 8 seperti yang ditunjukkan pada Gambar 4. 


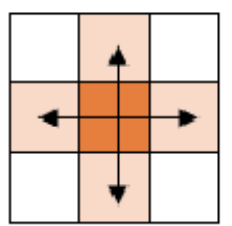

(a)

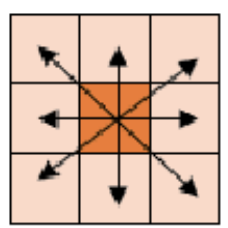

(b)

Gambar 4. (a) Arah Ketetanggaan 4 dan (b) Arah Ketetanggaan 8 (Fitri, Sahenda, dkk., 2021)

Area merupakan luasan yang didapatkan dari jumlah piksel-piksel penyusun obyek. Sedangkan perimeter merupakan keliling perbatasan obyek tersebut yang menghitung jumlah piksel dari batas obyek. Untuk mencari bentuk maka Persamaan sebagai berikut :

$$
S=\frac{\text { Perimeter }^{2}}{\text { Area }}
$$

Gray Level Co-Occurrence Matrix (GLCM) merupakan ekstraksi fitur tekstur yang berhubungan dengan transisi graylevel antara dua piksel menggunakan sebuah matriks cooccurrence. Matriks tersebut menggambarkan frekuensi munculnya pasangan dua piksel dengan intensitas tertentu dalam jarak $d$ dan arah sudut $\theta$ tertentu. Persamaan untuk mencari fitur GLCM (Fitri, dkk., 2020) :

$$
\begin{gathered}
\text { ASM }=\sum_{x=1}^{L} \sum_{y=1}^{L}(\operatorname{GLCM}(x, y))^{2} \\
\text { Kontras }=\sum_{x=1}^{L} \sum_{y=1}^{L}|x-y|^{2} \operatorname{GLCM}(x, y) \\
\text { IDM }=\sum_{x=1}^{L} \sum_{y=1}^{L} \frac{(\operatorname{GLCM}(x, y))^{2}}{1+(x-y)^{2}} \\
\text { Entropi }=\sum_{x=1}^{L} \sum_{y=1}^{L} \operatorname{GLCM}(x, y) \log \operatorname{GLCM}(x-y) \\
\text { Korelasi }=\sum_{x=1}^{L} \sum_{y=1}^{L} \frac{(x-\mu x)(y-\mu y)(\operatorname{GLCM}(x-y))}{\sigma x \sigma y}
\end{gathered}
$$

\subsection{Metode $K$-Nearest Neighbor}

Salah satu klasifikasi supervised learning pada poses pembelajarannya adalah metode $K$ Nearest Neighbor (KNN). Pembelajaran tersebut target klasifikasi sudah diketahui, sehingga dalam mengklasifikasikan data perlu ditentukan nilai $\mathrm{K}$ yang merupakan jumlah jarak terdekat dari data hasil klasifikasi. Kemudian data uji akan diklasifikasikan berdasarkan kelas terbanyak saat pengelompokkan berdasarkan nilai K. Untuk menghitung jarak terdekat,umumnya KNN menggunakan Persamaan Euclidean distance sebagai berikut (Fitri, dkk., 2021): 


$$
\operatorname{Jarak}\left(x_{x}, x_{y}\right)=\sqrt{\sum_{r=1}^{n}\left(x_{i r}-x_{i p}\right)^{2}}
$$

Dimana Xip adalah data latih dan Xir adalah data uji.

\subsection{Perhitungan Performance Method}

Teknik Receiver Operating Characteristic (ROC) digunakan untuk menghitung kemampuan (performance). Nilai karakteristik dibagi menjadi 4 yaitu True Positive (TP), True Negative (TN), False Positive (FP) dan False Negative (FN) (Fitri, 2017) yang digambarkan berdasarkan ilustrasi pada Gambar 5, sedangkan untuk mencari akurasi didapatkan menggunakan Persamaan (10).

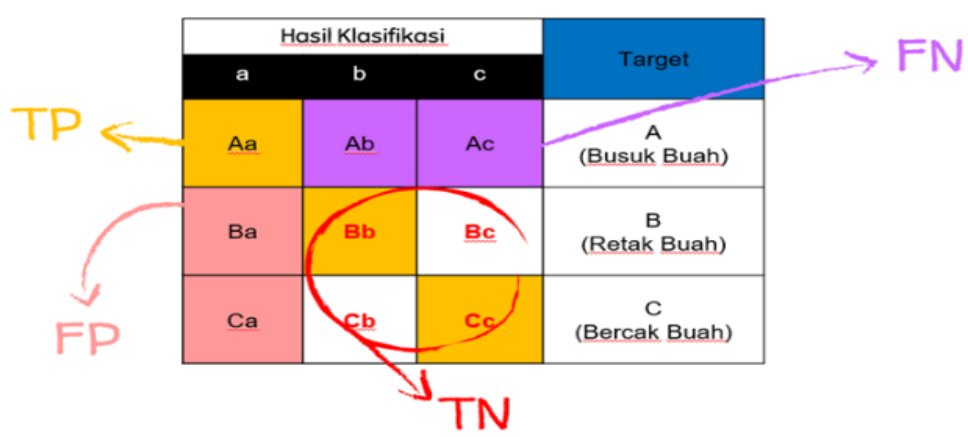

Gambar 5. Ilustrasi Confussion Matrix pada Perhitungan ROC

$$
\text { Akurasi }=\frac{T P}{T P+T N+F P+F N} \times 100 \%
$$

\section{HASIL DAN PEMBAHASAN}

Proses tersebut mengacu pada penelitian sebelumnya yaitu citra yang digunakan adalah citra komponen warna red (Fitri, dkk., 2020). Pada penelitian terdahulu, setelah mendapatkan citra komponen warna red seharusnya dilakukan penambahan kontras (contrast stretching), namun pada penelitian ini digunakan operasi lain seperti operasi negatif sehingga hasil citra negatif seperti Gambar 6.

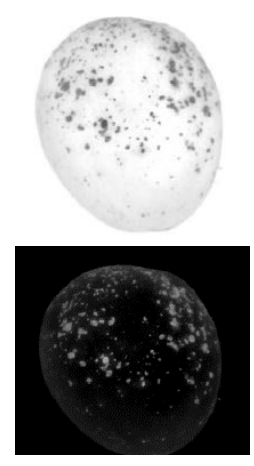

(a)

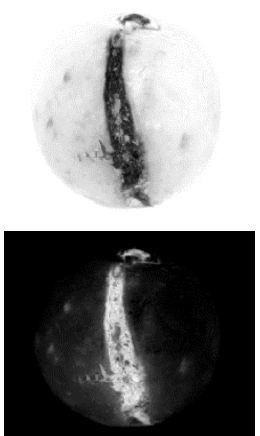

(b)

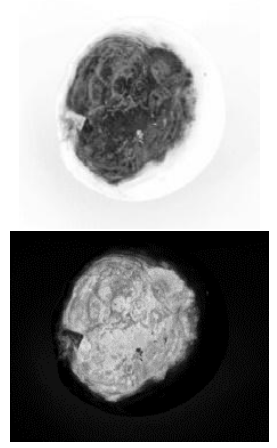

(c)

Gambar 6. Hasil Citra Negatif pada kelas (a) Bercak Buah, (b) Retak Buah dan (c) Busuk Buah 
Gambar 6 menunjukkan bahwa citra komponen red pada masing-masing kelas dilakukan operasi negatif pada masing-masing kelas. Pada citra hasil operasi negasi, terlihat jelas kerusakan mutu buah tomat yaitu bercak buah, retak buah dan busuk buah. Tahapan selanjutnya dilakukan proses segmentasi citra menggunakan teknik thresholding. Nilai ambang derajat keabuan $(T)$ yang digunakan, diperoleh dari histogram citra pada citra negatif atau negasi pada Gambar 7.

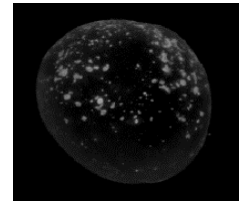

(a)

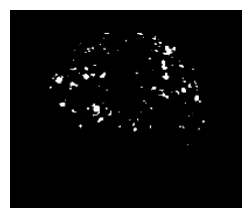

(c)

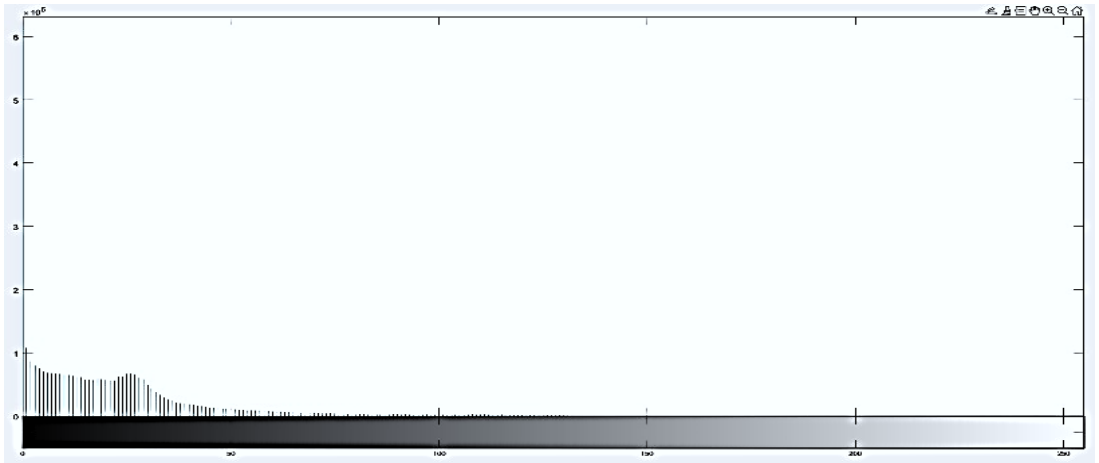

(b)

\section{Gambar 7. (a) Citra Negatif Kelas Bercak Buah, (b) Histogram dan (c) Hasil Citra Segmentasi}

Gambar 7 menunjukkan bahwa berdasarkan persamaan rumus (2) nilai ambang yang digunakan yaitu $\mathrm{T}=100$ berdasarkan citra histogram. Tahapan selanjutnya yaitu ekstraksi fitur (fitur morfologi dan fitur GLCM). Setelah proses tersebut, tahapan selanjutnya yang dilakukan adalah seleksi fitur. Fitur morfologi yang digunakan adalah perimeter, area dan bentuk, sementara fitur GLCM yang digunakan sebelum seleksi fitur adalah ASM, kontras, IDM, entropi dan korelasi. Peneliti melakukan seleksi fitur pada masing-masing fitur kemudian dilakukan proses klasifikasi menggunakan metode KNN dan hasilnya ditunjukkan pada Tabel 1 sementara Tampilan aplikasi klasifikasi pengolahan citra ditunjukkan pada Gambar 8.

\section{Tabel 1. Persentase Akurasi Metode KNN pada Seleksi Fitur}

\begin{tabular}{|l|c|c|c|c|}
\hline \multicolumn{1}{|c|}{ Fitur } & \multicolumn{3}{c|}{ Persentase Akurasi Tertinggi (\%) } \\
\cline { 2 - 4 } & Nilai K & Training & Nilai K & Testing \\
\hline Morfologi & 3 & 75 & $3,7,9$ & 60 \\
\hline $\begin{array}{l}\text { Morfologi + ASM, IDM, kontras, entropi dan korelasi } \\
0^{\circ}\end{array}$ & 3 & 87.1 & 3,5 & 66 \\
\hline $\begin{array}{l}\text { Morfologi + ASM, IDM, kontras, entropi dan korelasi } \\
45^{\circ}\end{array}$ & 3 & 85 & 3 & 63 \\
\hline $\begin{array}{l}\text { Morfologi + ASM, IDM, kontras, entropi dan korelasi } \\
90^{\circ}\end{array}$ & 3 & 87.1 & 5 & 70 \\
\hline $\begin{array}{l}\text { Morfologi + ASM, IDM, kontras, entropi dan korelasi } \\
135^{\circ}\end{array}$ & 3 & 89 & 3 & 66 \\
\hline Morfologi + ASM sudut $0^{\circ}, 45^{\circ}, 90^{\circ}$ dan $135^{\circ}$ & 3 & 77.6 & 7 & 70 \\
\hline Morfologi + IDM sudut $0^{\circ}, 45^{\circ}, 90^{\circ}$ dan $135^{\circ}$ & 3 & 80 & 3 & 66 \\
\hline Morfologi + Kontras sudut $0^{\circ}, 45^{\circ}, 90^{\circ}$ dan $135^{\circ}$ & 3 & 83.8 & 3 & 70 \\
\hline Morfologi + Entropi sudut $0^{\circ}, 45^{\circ}, 90^{\circ}$ dan $135^{\circ}$ & 3 & 80.9 & 3 & 63 \\
\hline Morfologi + Korelasi sudut $0^{\circ}, 45^{\circ}, 90^{\circ}$ dan $135^{\circ}$ & 3 & 86.6 & 3 & 70 \\
\hline Morfologi + Korelasi + Kontras $0^{\circ}, 45^{\circ}, 90^{\circ}$ dan $135^{\circ}$ & 3 & 86.1 & 3 & 63.3 \\
\hline Morfologi + Korelasi + ASM $0^{\circ}, 45^{\circ}, 90^{\circ}$ dan $135^{\circ}$ & 3 & 84.7 & 3 & 73 \\
\hline Morfologi + Korelasi + IDM $0^{\circ}, 45^{\circ}, 90^{\circ}$ dan $135^{\circ}$ & 3 & 86.1 & 3 & 66 \\
\hline Morfologi + Korelasi + Entropi $0^{\circ}, 45^{\circ}, 90^{\circ}$ dan $135^{\circ}$ & 3 & 84.7 & 3 & 66 \\
\hline
\end{tabular}




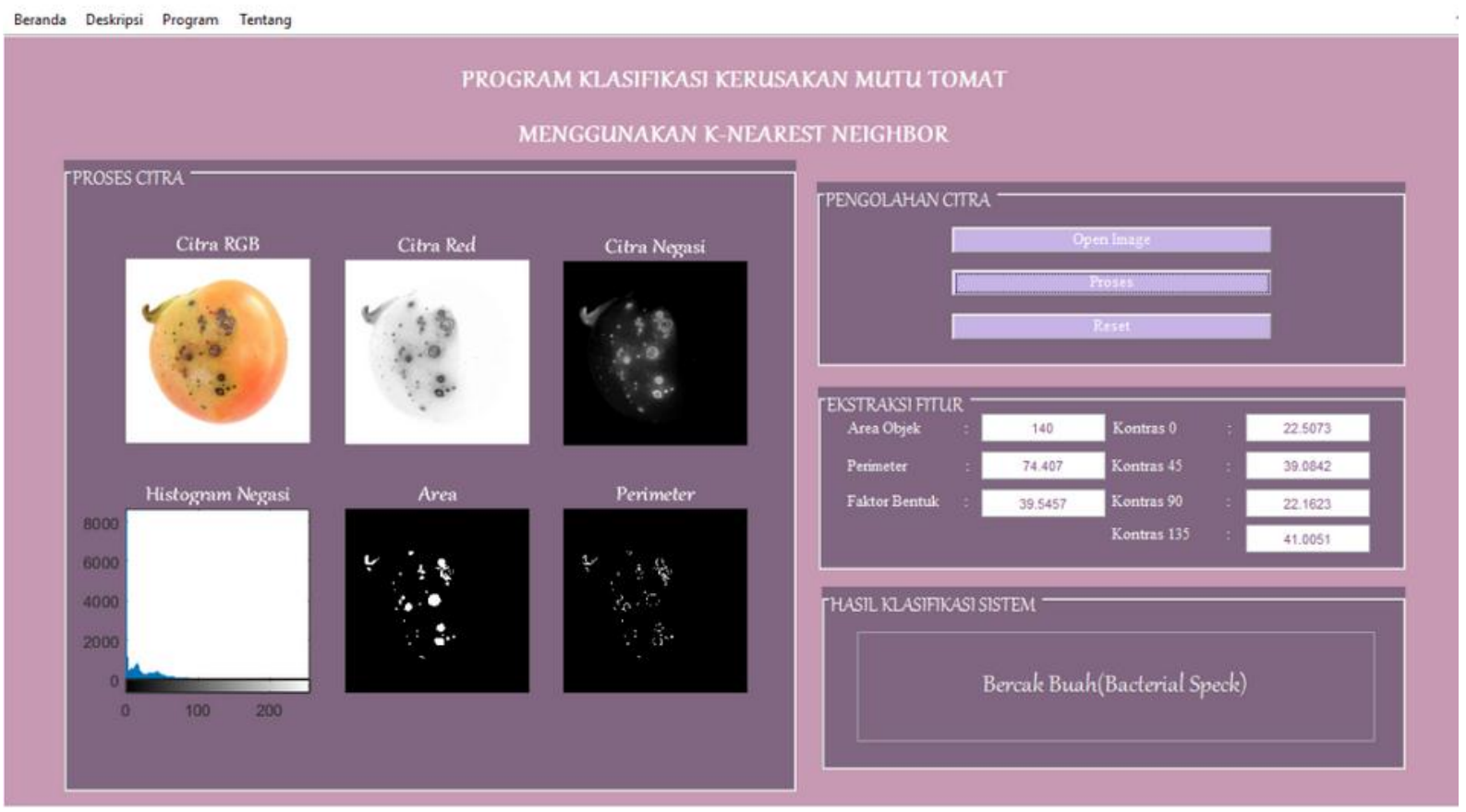

\section{Gambar 8. Tampilan Menu Pengolahan Citra dan Klasifikasi}

Berdasarkan hasil yang telah dipaparkan pada Tabel 1, Fitur yang paling optimal untuk mengidentifikasi kerusakan mutu buah tomat yaitu gabungan fitur morfologi dan korelasi pada semua sudut. Hal tersebut dilihat pada persentasi akurasi pelatihan sebesar $86.6 \%$ atau $87 \%$ sedangkan akurasi pengujiannya sebesar $70 \%$. Jika melihat dari akurasi pengujian, maka tingkat akurasi pengujian tertinggi sebesar $73 \%$ pada gabungan fitur morfologi, korelasi dan ASM pada semua sudut. Hasil perhitungan akurasi pelatihan dan pengujian pada variasi nilai $K=3$ menggunakan ilustrasi confusion matrix pada Gambar 4 sehingga confusion matrix untuk pelatihan (Tabel 2) dan pengujian (Tabel 3 ) dengan variasi nilai $\mathrm{K}=3$.

Tabel 2. Confusion Matrix Pelatihan

\begin{tabular}{|c|c|c|l|}
\hline \multicolumn{3}{|c|}{ Hasil Klasifikasi } & \multirow{2}{*}{ Target } \\
\hline a & b & c & \\
\hline 72 & 1 & 7 & A = Busuk Buah \\
\hline 5 & 75 & 0 & B = Retak Buah \\
\hline 12 & 3 & 35 & C = Bercak Buah \\
\hline
\end{tabular}

$\mathrm{TP}=182 ; \mathrm{TN}=3 ; \mathrm{FP}=17 ; \mathrm{FN}=8$

Akurasi Pelatihan $=\frac{T P}{T P+T N+F P+F N} \times 100 \%=\frac{186}{210} \times 100 \%=86.6 \%$

Tabel 3. Confusion Matrix Pengujian

\begin{tabular}{|c|c|c|l|}
\hline \multicolumn{3}{|c|}{ Hasil Klasifikasi } & \multirow{2}{*}{ Target } \\
\cline { 1 - 3 } a & b & c & \\
\hline 9 & 0 & 1 & A = Busuk Buah \\
\hline 0 & 10 & 0 & B = Retak Buah \\
\hline 8 & 0 & 2 & C = Bercak Buah \\
\hline
\end{tabular}

$\mathrm{TP}=21 ; \mathrm{TN}=12 ; \mathrm{FP}=8 ; \mathrm{FN}=1$ 
Akurasi Pengujian $=\frac{T P}{T P+T N+F P+F N} \times 100 \%=\frac{21}{30} \times 100 \%=70 \%$

Jika dibandingkan dengan penelitian terdahulu, yaitu penggunaan fitur morfologi dan fitur tekstur kontras dengan sudut mengikuti penelitian sebelumnya maka perbandingan hasilnya ditunjukkan pada Gambar 9. Pada penelitian terdahulu, menggunakan metode backpropagation didapatkan akurasi pelatihan $89.04 \%$ dan pengujian $81.11 \%$. Sementara hasil dari penelitian ini didapatkan tingkat akurasi pelatihan sebesar $83.8 \%$ atau $84 \%$ dan tingkat akurasi pengujian sebesar 70\% menggunakan metode KNN.

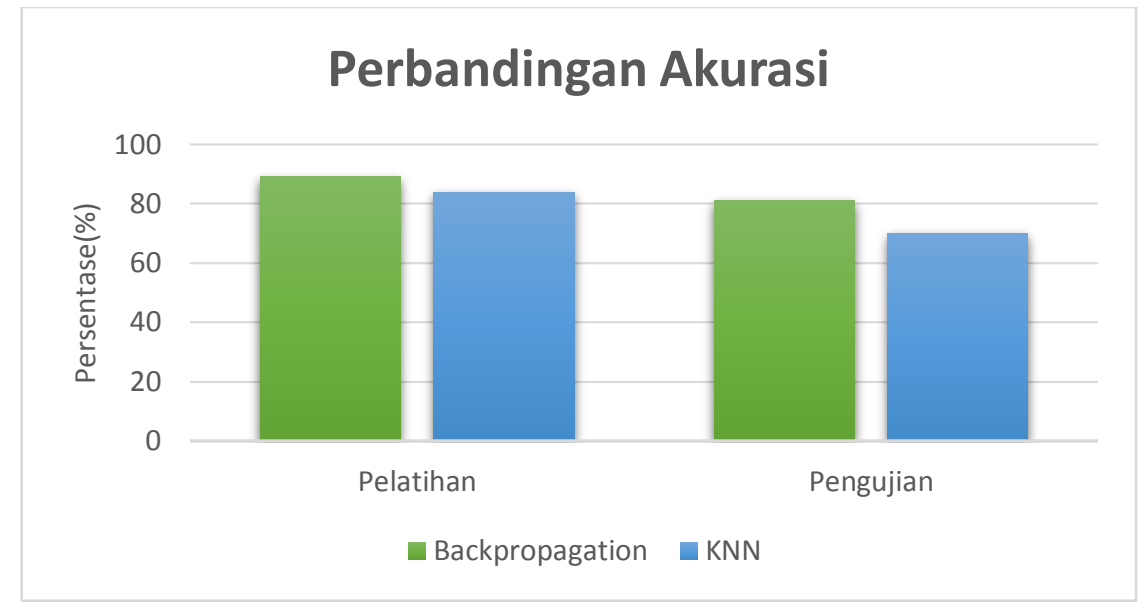

\section{Gambar 9. Perbandingan Akurasi Pelatihan dan Pengujian Metode Backpropagation dan KNN}

Gambar 9 menunjukkan bahwa metode Backpropagation lebih baik dalam mengidentifikasi kerusakan mutu tomat dibandingkan dengan metode $K$-Nearest Neighbor (KNN). Karena prinsip dari algoritma backpropagation, bila hasil klasifikasi tidak sesuai dengan target maka sistem akan melakukan pembaruan bobot sehingga hasil klasifikasi lebih baik. Sementara prinsip algoritma KNN dalam mengklasifikasi data yaitu menghitung jarak terdekat pada masing-masing data kemudian mengelompokkan data yang jarak dekat berdasarkan nilai $\mathrm{K}$ sehingga data tersebut dikelompokkan berdasarkan kelas prioritasnya.

\section{KESIMPULAN}

Jumlah data pelatihan sebanyak 210 data dan pengujian sebanyak 30 data maka terdapat dua model fitur yang optimal dan memiliki akurasi tertinggi yaitu gabungan fitur morfologi dan fitur tekstur korelasi dan gabungan fitur morfologi dan fitur tekstur korelasi ditambah ASM. Persentase akurasi pelatihan menggunakan metode $K$-Nearest Neighbor sebesar $86.6 \%$ sedangkan akurasi pengujiannya sebesar $70 \%$ jika menggunakan gabungan fitur morfologi dan fitur tekstur korelasi. Namun jika melihat dari akurasi pengujian, maka tingkat akurasi pengujian tertinggi sebesar $73 \%$ yaitu menggunakan gabungan fitur morfologi, korelasi dan ASM pada semua sudut. Perbedaan tingkat akurasi juga dipengaruhi dengan data yang digunakan pada proses pelatihan dan pengujian, maka ketika melakukan pengujian hendaknya memilih citra yang merepresentasikan data pelatihan. Namun apabila dibandingkan metode klasifikasi pada penelitian sebelumnya, maka metode $K$-Nearest Neighbor (KNN) tidak lebih baik mengklasifikasikan kerusakan mutu buah tomat bila dibandingkan dengan metode Backpropagation. Untuk pengembangan penelitian selanjutnya perlu diperbaiki metode pengolahan citra dan penambahan data untuk proses pelatihan dan pengujian. 


\section{DAFTAR RUJUKAN}

Aidah, S. N., \& Tim Penerbit KBM Indonesia. (2020). Ensiklopedi Tomat Deskripsi, Filosofi, Manfaat, Budidaya dan Peluang Bisnisnya. Karya Bakti Makmur (KBM) Indonesia.

Amalia, R. H. (2013). Identifikasi Citra Hama Tomat Menggunakan Gray Level Co-occurrence Matrix dan Klasifikasi Probabilistic Neural Network. Institut Pertanian Bogor.

Anggriawan, M. A., Ichwan, M., \& Utami, D. B. (2017). Pengenalan Tingkat Kematangan Tomat Berdasarkan Citra Warna Pada Studi Kasus Pembangunan Sistem Pemilihan Otomatis. Jurnal Teknik Informatika dan Sistem Informasi, 3(3). https://doi.org/10.28932/jutisi.v3i3.688

Astrianda, N. (2020). Klasifikasi Kematangan Buah Tomat Dengan Variasi Model Warna Menggunakan Support Vector Machine. VOCATECH: Vocational Education and Technology Journal, 1(2), 45-52. https://doi.org/10.38038/vocatech.v1i2.27

Badan Pusat Statistik. (2020). Produksi Tanaman Sayuran Tomat 2016-2020. https://www.bps.go.id

Fitri, Z. E. (2017). Klasifikasi Trombosit Pada Citra Hapusan Darah Tepi Berdasarkan Gray Level Co- Occurrence Matrix Menggunakan Backpropagation. Institut Teknologi Sepuluh Nopember.

Fitri, Z. E., Nugroho, W. B., Madjid, A., \& Imron, A. M. N. (2021). Comparison of Neural Network Methods for Classification of Banana Varieties (Musa paradiasaca). Jurnal Rekayasa Elektrika, 172). https://doi.org/10.17529/jre.v17i2.20806

Fitri, Z. E., Purnama, I. K. E., Pramunanto, E., \& Purnomo, M. H. (2017). A comparison of platelets classification from digitalization microscopic peripheral blood smear. 2017 International Seminar on Intelligent Technology and Its Application: Strengthening the Link Between University Research and Industry to Support ASEAN Energy Sector, ISITIA 2017 - Proceeding, 2017-Janua, (pp. 356-361). https://doi.org/10.1109/ISITIA.2017.8124109

Fitri, Z. E., Rizkiyah, R., Madjid, A., \& Imron, A. M. N. (2020). Penerapan Neural Network untuk Klasifkasi Kerusakan Mutu Tomat. Jurnal Rekayasa Elektrika, 16(1), 44-49. https://doi.org/10.17529/jre.v16i1.15535

Fitri, Z. E., Sahenda, L. N., Puspitasari, P. S. D., Destarianto, P., Rukmi, D. L., \& Imron, A. M. N. (2021). The Classification of Acute Respiratory Infection ( ARI ) Bacteria Based on K-Nearest Neighbor. Lontar Komputer: Jurnal IImiah Teknologi Informasi, 12(2), 91101. 
Gumawang, G. E., M., R. R., \& Setlaningsih, C. (2017). Perancangan dan Implementasi untuk Penyortiran Buah Tomat (Lycopersicum Esculentum) Dengan Metode Learning Vector Quantizationprototype. e-Proceeding of Engineering, 4(3), 4177-4185.

Nanda Imron, A. M., \& Fitri, Z. E. (2019). A Classification of Platelets in Peripheral Blood Smear Image as an Early Detection of Myeloproliferative Syndrome Using Gray Level Co-Occurence Matrix. Journal of Physics: Conference Series, 1201(1). https://doi.org/10.1088/1742-6596/1201/1/012049

Nurhakim, Y. I. (2019). Sukses Budidaya Tumpang Sari Cabai \& Tomat Praktis \& Menguntungkan. IImu Cemerlang Group.

Sukmandaru, P. (2019). Identifikasi Penyakit Tanaman Tomat Berdasarkan Citra Daun Menggunakan Metode Gray Level Co-Occurrence Matrix (GLCM) dan K-Nearest Neighbor (KNN). Universitas Pembangunan Nasional Veteran Yogyakarta.

Syukur, M., Saputra, H. E., \& Hermanto, R. (2015). Bertanam Tomat di Musim Hujan. Penebar Swadaya Group. 